Research Paper

\title{
The impact of interleukin-10 (IL-10) gene 4 polymorphisms on peripheral blood IL-10 variation and prostate cancer risk based on published studies
}

\author{
Tingting Men ${ }^{1, *}$, Cuicui $\mathbf{Y u}^{2, *}$, Dan Wang ${ }^{3}$, Fang Liu ${ }^{3}$, Jingjing $\mathbf{L i}^{3}$, Xiaoying $\mathbf{Q i}^{3}$, \\ Chunhua Yang ${ }^{3}$, Wenguo Jiang $^{3}$, Xiaodan Wei ${ }^{3}$, Xuri $\mathrm{Li}^{3}$, Bin Wang ${ }^{4}$, Jia $\mathrm{Mi}^{3}$ and \\ Geng Tian ${ }^{3}$ \\ ${ }^{1}$ School of Nursing, Binzhou Medical University, Yantai, Shandong, China \\ ${ }^{2}$ Department of Anesthesiology, Yantai Yu Huang Ding Hospital, Yantai, Shandong, China \\ ${ }^{3}$ Medicine and Pharmacy Research Center, Binzhou Medical University, Yantai, Shandong, China \\ ${ }^{4}$ Institute of Molecular Imaging, Binzhou Medical University, Yantai, Shandong, China \\ *These authors have contributed equally to this work \\ Correspondence to: Geng Tian, email: tiangengshandong@yeah.net \\ Jia Mi, email: Jia.mi@kemi.uu.se \\ Bin Wang, email: binwang001@aliyun.com
}

Keywords: prostate cancer, interleukin-10, polymorphism, peripheral blood interleukin-10, meta-analysis

Received: December 16, $2016 \quad$ Accepted: April 11, 2017 Published: April 29, 2017

Copyright: Men et al. This is an open-access article distributed under the terms of the Creative Commons Attribution License 3.0 (CC BY 3.0), which permits unrestricted use, distribution, and reproduction in any medium, provided the original author and source are credited.

\section{ABSTRACT}

This study purported to investigate the impact of interleukin-10 (IL-10) gene 4 polymorphisms (-1082G $>A,-819 T>C,-592 A>C$ and $210 T>C)$ on peripheral blood IL-10 variation and prostate cancer ( $\mathrm{PCa}$ ) risk, with a special consideration given to various origins of between-study heterogeneity. 2 researchers independently fulfilled literature retrieval, quality assessment and information collection. Sub-grouped analyses per ethnicity, continent, design type, control source, genotyping procedure, genotype validation, age-matched status, study sample size, quality score and controls' mean age were conducted, respectively. Total 17 unduplicated studies (patients/controls: 7561/8101) were assessable for PCa risk, and 4 unduplicated studies (1189 subjects) for peripheral blood IL-10 variation. Pooling all assessable studies identified a marginally significant association between the $-1082 \mathrm{~A}$ allele and increased PCa risk (odds ratio $(O R)=1.10,95 \%$ confidence interval $[C I]: 1.00$ to 1.21 ) (Heterogeneity $I^{2}=64.3 \%$ ), and no significance was detected in sub-grouped analyses of this polymorphism. Contrastingly, the $-592 \mathrm{C}$ allele was significantly associated with reduced PCa risk in both prospective $(\mathrm{OR}=0.85,95 \% \mathrm{CI}: 0.77$ to 0.95$)$ and population-based $(\mathrm{OR}=0.92$, 95\% CI: 0.84 to 1.00 ) studies (Heterogeneity $I^{2}=0.0 \%$ and $18.1 \%$ ). Moreover, carriers of combined -592CA/CC genotypes had a significant higher level of peripheral blood IL10 than the -592AA genotype carriers (weighted mean difference $=0.45$ and $0.54 \mathrm{mg}$ / $\mathrm{dL}, 95 \% \mathrm{CI}: 0.23$ to 0.67 and 0.30 to 0.39 ). The above comparisons possessed a low probability of publication bias. In sum, our findings suggested that IL-10 gene -592A >C polymorphism may represent a promising candidate locus for the occurrence of PCa, and further signified a contributing role of this polymorphism in prostate carcinogenesis.

\section{INTRODUCTION}

Prostate cancer $(\mathrm{PCa})$ is frequently occurring among men, and its mortality is continuing to rise, especially in some Western countries [1,2]. As reported by the World Cancer Research Fund International (http://www. wcrf.org/int/cancer-facts-figures/data-specific-cancers/ prostate-cancer-statistics), $\mathrm{PCa}$ represents 8 per cent 
of all new cancer cases and 15 per cent in men in 2012 . The latest statistics from the American Cancer Society have predicted that $\mathrm{PCa}$ accounts for 21 per cent of all new cancer cases in men, and for 8 per cent of all male cancer deaths in the United States [3]. A growing body of evidence has suggested that chronic inflammation plays an important role in modulating cellular events during the course of prostate carcinogenesis through disrupting immune responses and altering tumor microenvironments $[4,5]$. As an apt illustration of this evidence, the viability of PCa PC-3 cells was found to be significantly correlated with the ratio of pro-inflammatory to anti-inflammatory cytokines in macrophage-conditioned media [6]. Interleukin-10 (IL-10) is a key anti-inflammatory cytokine that can down-regulate pro-inflammatory responses [7]. IL-10 is secreted by Th2 cells, and its production is involved in the regulation of immune and inflammatory responses [8]. Based on the above evidence, it is tempting for us to assume a regulatory role of IL-10 in prostate carcinogenesis.

As we all know, PCa is a malignant cancer, and it exhibits familial aggregation [9]. Some studies have reported that there is a strong hereditary component in the development of PCa, which accounts for 5 to 10 per cent of all cases [10-12]. It is of crucial importance to pinpoint genetic determinants that can explain the interindividual differences in susceptibility to $\mathrm{PCa}$. Given the promising candidacy of IL-10 in prostate carcinogenesis, a large number of investigators were inspired to hunt for IL-10 genetic alternations strongly associated with PCa susceptibility, while unfortunately their results remained indeterminate [13-17]. This may attribute to between-study distinctions in respect of ethnicity, design type, sample collection, statistical power and so forth. In this regard, two previous meta-analyses with the same purport published in 2011 [18, 19] have left some critical methodological questions unanswered, mainly revolving around the exploratory testing of between-study heterogeneity. We thereby decided to update the two meta-analyses with the incorporation of additional studies publicly available by November 2016 . This paper purported to integrate the findings from 17 assessable studies to investigate the impact of IL-10 gene 4 polymorphisms on peripheral blood IL-10 variation and $\mathrm{PCa}$ risk. In the meantime, a special consideration was given to probe into various origins of between-study heterogeneity.

\section{RESULTS}

\section{Study selection}

Literature retrieval of three public sources using prior key subjects identified a total of 114 articles written in the English language. Therein, 97 articles were debarred due to some precise reasons as elucidated in Figure 1.
The rest 17 articles met our inclusive criteria, and were pooled consequently [13-17, 20-31]. The association of IL-10 gene 4 polymorphisms with PCa risk was examined in 16 articles [13-17, 20, 21, 23-31] incorporating 17 unduplicated studies (7561 patients and 8101 controls), and with peripheral blood IL-10 variation in 2 articles [21, 22] incorporating 4 unduplicated studies (1189 subjects). Table 1 shows the characteristics of 17 studies under investigation.

8 of 17 studies enrolled Caucasians, 4 studies enrolled Asians, 2 studies enrolled African-Americans and 3 studies enrolled mixed-ethnicity populations of Caucasian and African-American. 11 studies followed retrospective design and 6 studies followed prospective design. 10 studies were population-based studies, and 7 studies were hospital-based studies. IL-10 genotypes were determined by TaqMan in 7 studies, by PCRrelated methods in 7 studies and by MassARRAY in 3 studies. Only 11 studies validated the accuracy of genotypes, either internally or externally. Age was reported to be matched in frequency between PCa patients and controls in 11 studies. 9 studies possessed a total sample size of less than 600 (the median cut-off point of total sample sizes of all assessable studies), and 8 studies involved more than 600 subjects. Quality score of 17 studies ranged from 6 to 11, and its mean value was 8.47. To be specific, 15, 9, 11 and 3 studies were assessable to respectively investigate the impact of IL10 gene $-1082 \mathrm{G}>\mathrm{A},-819 \mathrm{~T}>\mathrm{C},-592 \mathrm{~A}>\mathrm{C}$ and $210 \mathrm{~T}>\mathrm{C}$ polymorphisms on $\mathrm{PCa}$ risk.

\section{IL-10 genetic polymorphisms and PCa risk: Overall analyses}

The prediction of IL-10 gene each polymorphism for PCa risk was explored by comparing mutant allele with wild allele (termed the allele model), heterozygous genotype with wild genotype (termed the hetero-genotype model), homozygote genotype with wild genotype (termed the homo-genotype model) and combined heterozygote/ homozygous genotypes with wild genotype (termed the dominant model), respectively. Overall risk prediction is offered in Table 2. The -1082A allele and the -1082AA genotype were marginally associated with increased $\mathrm{PCa}$ risk, with an OR of respectively being 1.10 (95\% CI: 1.00 to 1.21 ) and 1.23 (95\% CI: 1.01 to 1.50 ) (Heterogeneity $I^{2}=64.3 \%$ and $\left.63.2 \%\right)$. No hints of significant association and between-study heterogeneity were observed for the other three polymorphisms under investigation. Both Begg's and Egger's tests indicated no statistical evidence of publication bias. The Begg's funnel plots seemed symmetrical for all 4 polymorphisms (Figures 2 and Figure 3). As reflected by the filled funnel plots (Figures 2 and Figure 3), there were respectively 2 studies and 1 study required for $-819 \mathrm{~T}>\mathrm{C}$ and $-592 \mathrm{~A}>\mathrm{C}$ polymorphisms respectively to render funnel plots symmetrical. 
IL-10 genetic polymorphisms and PCa risk: Subgrouped analyses

As only 3 studies were assessable for $210 \mathrm{~T}>\mathrm{C}$ polymorphism, its association with $\mathrm{PCa}$ risk was unlikely to be of use in sub-grouped analyses. For the rest 3 polymorphisms, sub-grouped analyses were undertaken to probe into various origins of heterogeneity, per ethnicity, continent, design type, control source, genotyping procedure, genotype validation, matching status, study sample size, quality score (at the median cut-off point of 9) and controls' mean age ( $>50$ years old), respectively (Table 3 ). For $-1082 \mathrm{G}>\mathrm{A}$, there was marginal significance in

Literature retrieval of PubMed, EMBASE and Web of Knowledge for articles written in English language as of November 14, 2016

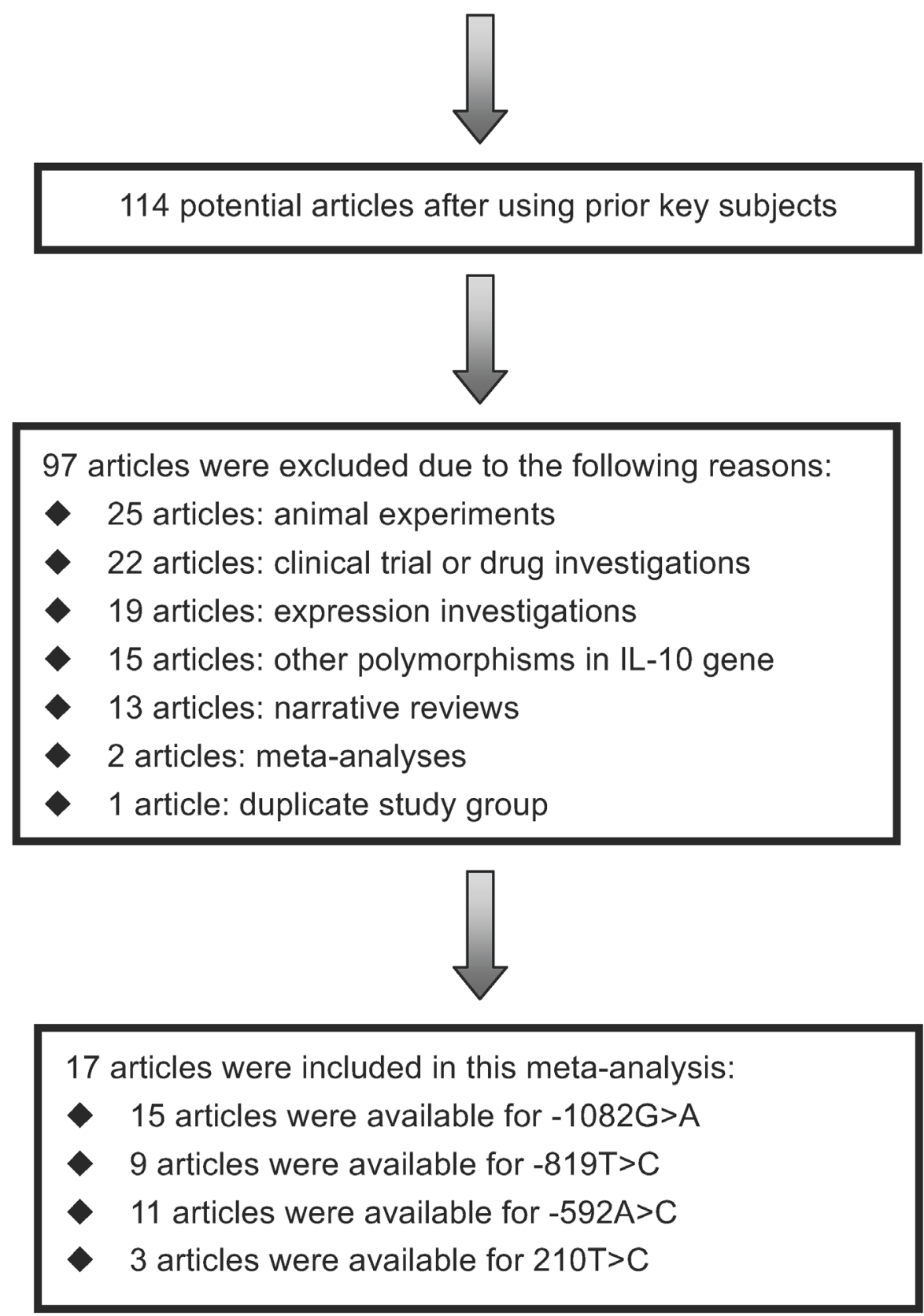

Figure 1: The streamline plot of article selection for the present meta-analysis. 
Table 1: The characteristics of 17 studies for the association of interleukin-10 genetic polymorphisms with prostate cancer risk

\begin{tabular}{|c|c|c|c|c|c|c|c|c|c|c|c|}
\hline Author & Year & Region & Ethnicity & Design type & $\begin{array}{l}\text { Control } \\
\text { source }\end{array}$ & $\begin{array}{l}\text { Genotyping } \\
\text { procedure }\end{array}$ & Validation & Match & $\begin{array}{l}\text { Quality } \\
\text { score }\end{array}$ & Patients & Controls \\
\hline Winchester & 2015 & USA & Caucasian & Prospective & Population & MassARRAY & YES & YES & 11 & 881 & 848 \\
\hline Horvat & 2015 & Croatia & Caucasian & Prospective & Hospital & PCR-related & N.R. & YES & 9 & 120 & 120 \\
\hline Dwivedi & 2015 & India & Asian & Retrospective & Hospital & PCR-related & YES & YES & 8 & 291 & 291 \\
\hline Ianni & 2013 & Italy & Caucasian & Retrospective & Population & PCR-related & YES & N.R. & 7 & 244 & 259 \\
\hline Dluzniewski & 2012 & USA & Mixed & Prospective & Population & MassARRAY & N.R. & YES & 8 & 484 & 484 \\
\hline VanCleave & 2010 & USA & $\begin{array}{l}\text { African- } \\
\text { American }\end{array}$ & Retrospective & Hospital & TaqMan & YES & N.R. & 10 & 193 & 666 \\
\hline Liu & 2010 & China & Asian & Retrospective & Population & PCR-related & YES & YES & 9 & 262 & 270 \\
\hline Wang & 2009 & USA & Mixed & Prospective & Population & TaqMan & N.R. & YES & 7 & 264 & 264 \\
\hline Kesarwani & 2009 & India & Asian & Retrospective & Hospital & PCR-related & YES & YES & 9 & 159 & 259 \\
\hline Zabaleta (C) & 2008 & USA & Caucasian & Retrospective & Hospital & TaqMan & YES & N.R. & 9 & 475 & 394 \\
\hline Zabaleta (AA) & 2008 & USA & $\begin{array}{l}\text { African- } \\
\text { American }\end{array}$ & Retrospective & Hospital & TaqMan & YES & N.R. & 9 & 66 & 129 \\
\hline Omrani & 2008 & Iran & Asian & Retrospective & Hospital & PCR-related & N.R. & N.R. & 6 & 41 & 103 \\
\hline Faupel-Badger & 2008 & Finland & Caucasian & Prospective & Population & TaqMan & YES & YES & 9 & 584 & 584 \\
\hline Eder & 2007 & Austria & Caucasian & Retrospective & Population & TaqMan & YES & YES & 7 & 547 & 545 \\
\hline Michaud & 2006 & USA & Mixed & Prospective & Population & TaqMan & YES & YES & 11 & 1320 & 1842 \\
\hline $\mathrm{Xu}$ & 2005 & Sweden & Caucasian & Retrospective & Population & MassARRAY & N.R. & YES & 8 & 1383 & 780 \\
\hline McCarron & 2002 & UK & Caucasian & Retrospective & Population & PCR-related & N.R. & N.R. & 7 & 247 & 263 \\
\hline
\end{tabular}

Abbreviations: PCR: polymerase chain reaction; N.R.: not reported.

Caucasians, when comparing the $-1082 \mathrm{~A}$ allele with the $-1082 \mathrm{G}$ allele (OR=1.13, $95 \% \mathrm{CI}$ : 0.97 to 1.32$)$. Further by continental regions, the association of $-1082 \mathrm{~A}$ allele with $\mathrm{PCa}$ risk was strengthened in studies from European countries (OR=1.24, 95\% CI: 1.01 to 1.54$)$. In population-based studies, the $-1082 \mathrm{~A}$ allele was associated with a 1.15 -fold increased PCa risk $(95 \%$ CI: 1.02 to 1.31$)$. Genotype misclassification might be a possible origin of heterogeneity, as significance was noticed after confining analysis to studies lacking genotype validation. In addition, in the studies with quality score $\leq 9$, there was a marginally increased $\mathrm{PCa}$ risk for the comparison of the $-1082 \mathrm{~A}$ allele with the $-1082 \mathrm{G}$ allele (OR=1.14, 95\% CI: 1.00 to 1.29$)$.

For $-819 \mathrm{~T}>\mathrm{C}$, there was no observed significance in all subgroups, with an exception of the studies with controls' mean age $>50$ years old $(\mathrm{OR}=1.12,95 \%$ CI: 1.02 to 1.23 ). For $-592 \mathrm{~A}>\mathrm{C}$, association of the $-592 \mathrm{C}$ allele with reduced $\mathrm{PCa}$ risk was significant in the studies with mixedethnicity populations (Caucasians and African-Americans) ( $\mathrm{OR}=0.84,95 \%$ CI: 0.71 to 1.00 ), as well as in prospective studies (OR $=0.85,95 \%$ CI: 0.77 to 0.95$)$ and populationbased studies (OR=0.92, $95 \% \mathrm{CI}$ : 0.84 to 1.00$)$.

\section{IL-10 genetic polymorphisms and peripheral blood IL-10}

The characteristics of 4 studies for the association of interleukin-10 gene -592A/C and $-819 \mathrm{~T}>\mathrm{C}$ polymorphisms with peripheral blood interleukin-10 variation are presented in Supplementary Table 2. Mean differences in peripheral blood IL-10 across the genotypes of $-819 \mathrm{~T}>\mathrm{C}$ and $-592 \mathrm{~A}>\mathrm{C}$ polymorphisms are displayed in Figure 4. Carriers of the $-819 \mathrm{CC}$ genotype had a significant higher level of peripheral blood IL-10 than the -819TT genotype carriers $(\mathrm{WMD}=0.54 \mathrm{mg} / \mathrm{dL}, 95 \% \mathrm{CI}: 0.30$ to 0.79 ), which no significance was noticed between carriers of the -819CT genotype and the -819TT genotype. For -592A $>C$, carriers of the $-592 \mathrm{CA}$ and the $-592 \mathrm{CC}$ genotypes had a significant higher level of peripheral blood IL-10 than the -592AA genotype carriers (WMD $=0.45$ and $0.54 \mathrm{mg}$ / dL, $95 \%$ CI: 0.23 to 0.67 and 0.30 to 0.39$)$. There was no heterogeneity for above comparisons $\left(I^{2}=0.0 \%\right)$.

\section{Meta-regression analysis}

After taking age, per cent of smokers, family $\mathrm{PCa}$ history and PSA as independent variables, a meta-regression 
Table 2: Overall association of interleukin-10 gene 4 polymorphisms with prostate cancer risk under 4 genetic models

\begin{tabular}{|c|c|c|c|c|c|c|c|c|c|}
\hline Genetic models & Num. & OR & $95 \%$ CI & $\mathbf{P}$ & $I^{2}$ & $P_{\text {Begg }}$ & $P_{\text {Egger }}$ & $\begin{array}{c}\text { Num. of } \\
\text { missing studies }\end{array}$ & $\begin{array}{l}\text { Filled OR, } \\
95 \% \text { CI, P }\end{array}$ \\
\hline \multicolumn{10}{|l|}{ Allele model } \\
\hline$-1082 \mathrm{G}>\mathrm{A}$ & 15 & 1.10 & 1.00 to 1.21 & 0.056 & $64.3 \%$ & 0.692 & 0.284 & 0 & \\
\hline$-819 \mathrm{~T}>\mathrm{C}$ & 9 & 1.04 & 0.94 to 1.15 & 0.490 & $46.8 \%$ & 0.251 & 0.961 & 2 & $\begin{array}{c}1.01,0.92 \text { to } \\
1.11,0.244\end{array}$ \\
\hline$-592 \mathrm{~A}>\mathrm{C}$ & 11 & 0.96 & 0.89 to 1.04 & 0.316 & $24.3 \%$ & 0.553 & 0.470 & 1 & $\begin{array}{c}0.96,0.89 \text { to } \\
1.03,0.235\end{array}$ \\
\hline $210 \mathrm{~T}>\mathrm{C}$ & 3 & 0.63 & 0.88 to 1.04 & 0.283 & $8.2 \%$ & 0.296 & 0.254 & 0 & \\
\hline \multicolumn{10}{|c|}{ Hetero-genotype model } \\
\hline$-1082 \mathrm{G}>\mathrm{A}$ & 15 & 1.11 & 0.95 to 1.30 & 0.200 & $56.5 \%$ & 0.621 & 0.483 & 0 & \\
\hline$-819 \mathrm{~T}>\mathrm{C}$ & 9 & 0.97 & 0.84 to 1.13 & 0.717 & $0.0 \%$ & 0.466 & 0.523 & 0 & \\
\hline$-592 \mathrm{~A}>\mathrm{C}$ & 11 & 0.92 & 0.80 to 1.07 & 0.296 & $0.0 \%$ & 0.350 & 0.351 & 0 & \\
\hline $210 \mathrm{~T}>\mathrm{C}$ & 3 & 0.97 & 0.86 to 1.10 & 0.657 & $0.0 \%$ & 0.296 & 0.258 & 0 & \\
\hline \multicolumn{10}{|c|}{ Homo-genotype model } \\
\hline$-1082 \mathrm{G}>\mathrm{A}$ & 15 & 1.23 & 1.01 to 1.50 & 0.039 & $63.2 \%$ & 0.488 & 0.232 & 0 & \\
\hline$-819 \mathrm{~T}>\mathrm{C}$ & 9 & 1.08 & 0.89 to 1.31 & 0.431 & $23.8 \%$ & 0.602 & 0.740 & 1 & $\begin{array}{c}1.06,0.88 \text { to } \\
1.28,0.626\end{array}$ \\
\hline$-592 \mathrm{~A}>\mathrm{C}$ & 11 & 0.92 & 0.78 to 1.07 & 0.261 & $0.0 \%$ & 1.000 & 0.959 & 0 & \\
\hline $210 \mathrm{~T}>\mathrm{C}$ & 3 & 0.92 & 0.78 to 1.08 & 0.295 & $10.4 \%$ & 0.296 & 0.255 & 0 & \\
\hline \multicolumn{10}{|l|}{ Dominant model } \\
\hline$-1082 \mathrm{G}>\mathrm{A}$ & 15 & 1.15 & 0.98 to 1.36 & 0.095 & $63.7 \%$ & 0.921 & 0.434 & 0 & \\
\hline$-819 \mathrm{~T}>\mathrm{C}$ & 9 & 1.02 & 0.88 to 1.18 & 0.813 & $7.2 \%$ & 0.175 & 0.498 & 0 & \\
\hline$-592 \mathrm{~A}>\mathrm{C}$ & 11 & 0.93 & 0.81 to 1.07 & 0.295 & $0.0 \%$ & 0.213 & 0.312 & 0 & \\
\hline $210 \mathrm{~T}>\mathrm{C}$ & 3 & 0.96 & 0.85 to 1.08 & 0.456 & $0.0 \%$ & 0.296 & 0.302 & 0 & \\
\hline
\end{tabular}

Abbreviations: OR: odds ratio; 95\% CI: 95 per cent confidence interval; $P$ : inconsistency index.

model was constructed. Unfortunately, none of these 4 variables showed a significant impact on the association of IL-10 gene 4 polymorphisms with PCa risk $(\mathrm{P}>0.05)$.

\section{DISCUSSION}

In the present study, we meta-analytically investigated the impact of IL-10 gene 4 polymorphisms on peripheral blood IL-10 variation and PCa risk. The most important observation was that the mutation of $-592 \mathrm{~A}>\mathrm{C}$ polymorphism was significantly associated with reduced PCa risk and increased peripheral blood IL-10 level. Moreover, ethnicity, design type and control source served as the possible origins of heterogeneity. As the $-592 \mathrm{~A}>\mathrm{C}$ polymorphism is in IL-10 gene promoter region, it appears reasonable to postulate that this polymorphism may alter an individual's susceptibility to PCa risk by regulating peripheral blood IL-10 level.

As indicated by two previous meta-analyses, there were no signs of statistical significance between IL-10 gene 3 widely-studied promoter polymorphisms $(-1082 \mathrm{G}>\mathrm{A},-819 \mathrm{~T}>\mathrm{C}$ and $-592 \mathrm{~A}>\mathrm{C}$ polymorphisms $)$ and $\mathrm{PCa}$ risk under all possible genetic models of inheritance $[18,19]$. By contrast, in this updated meta-analysis, we integrated the results of 17 articles and found that IL-10 gene $-592 \mathrm{~A}>\mathrm{C}$ polymorphism was significantly associated with $\mathrm{PCa}$ risk in both prospective and population-based studies. In addition, we observed a significant relation between $-592 \mathrm{~A}>\mathrm{C}$ polymorphism and peripheral blood IL-10 variation, which can lend some credence to the functional role of this polymorphism in prostate carcinogenesis. In support of this claim, the $-592 \mathrm{C}$ allele was reported to be associated with a higher level of IL-10 

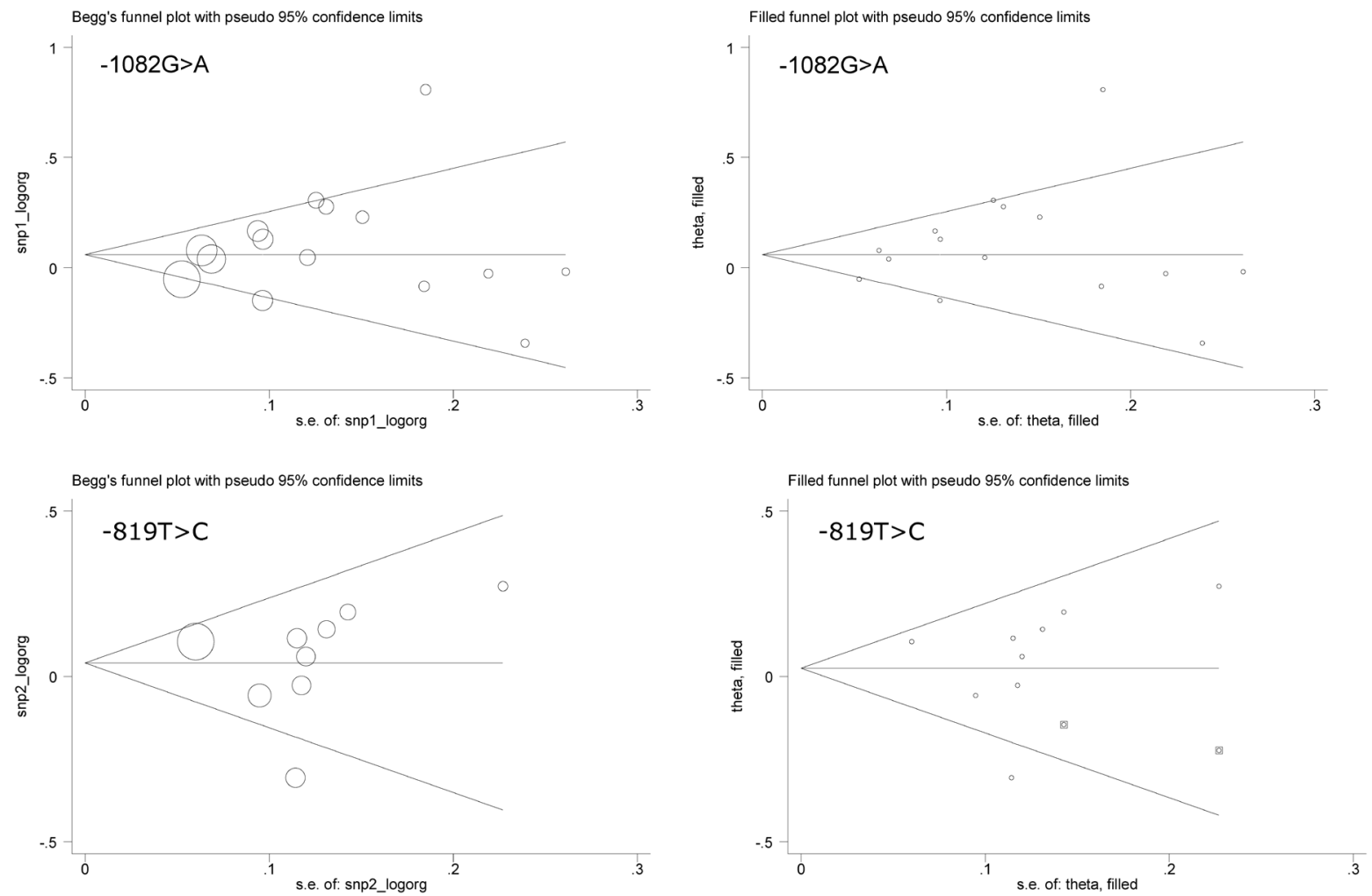

Figure 2: The Begg's (the left panels) and filled (the right panels) funnel plots for interleukin-10 gene $-1082 G>A$ and $-819 T>C$ polymorphisms under the allelic model.
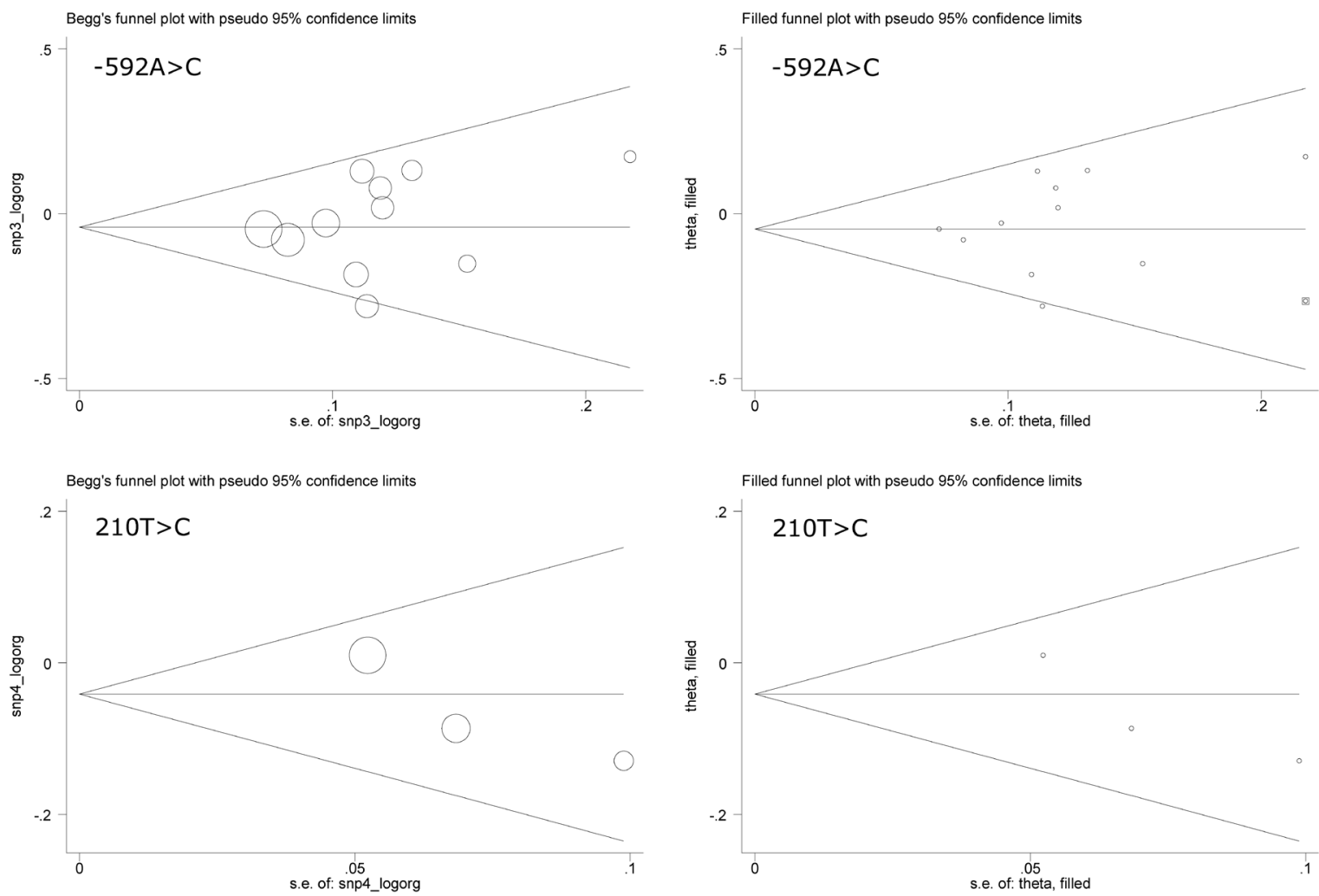

Figure 3: The Begg's (the left panels) and filled (the right panels) funnel plots for interleukin-10 gene $-592 \mathrm{~A}>\mathrm{C}$ and 210T $>$ C polymorphisms under the allelic model. 
Table 3: Sub-grouped association of interleukin-10 gene 3 polymorphisms with prostate cancer risk

\begin{tabular}{|c|c|c|c|c|c|c|c|c|c|c|c|c|c|c|c|c|}
\hline \multirow[b]{2}{*}{ Subgroups } & & \multicolumn{5}{|c|}{$-1082 G>A$ polymorphism } & \multicolumn{5}{|c|}{$-819 \mathrm{~T}>\mathrm{C}$ polymorphism } & \multicolumn{5}{|c|}{$-592 \mathrm{~A}>\mathrm{C}$ polymorphism } \\
\hline & & Num. & OR & $\begin{array}{c}95 \% \\
\text { CI }\end{array}$ & $\mathbf{P}$ & $I^{2}$ & Num. & OR & $\begin{array}{c}95 \% \\
\text { CI }\end{array}$ & $\mathbf{P}$ & $r^{2}$ & Num. & OR & $\begin{array}{c}95 \% \\
\text { CI }\end{array}$ & $\mathbf{P}$ & $r^{2}$ \\
\hline \multirow[t]{4}{*}{ Ethnicity } & Caucasian & 7 & 1.13 & $\begin{array}{c}0.97 \text { to } \\
1.32\end{array}$ & 0.115 & $75.8 \%$ & 3 & 0.92 & $\begin{array}{c}0.73 \text { to } \\
1.15\end{array}$ & 0.474 & $70.8 \%$ & 5 & 0.94 & $\begin{array}{c}0.85 \text { to } \\
1.05\end{array}$ & 0.276 & $41.7 \%$ \\
\hline & Asian & 3 & 0.99 & $\begin{array}{c}0.70 \text { to } \\
1.41\end{array}$ & 0.971 & $52.2 \%$ & 3 & 1.09 & $\begin{array}{c}0.94 \text { to } \\
1.26\end{array}$ & 0.238 & $0.0 \%$ & 2 & 1.11 & $\begin{array}{c}0.93 \text { to } \\
1.32\end{array}$ & 0.249 & $0.0 \%$ \\
\hline & $\begin{array}{l}\text { African- } \\
\text { American }\end{array}$ & 2 & 1.03 & $\begin{array}{c}0.84 \text { to } \\
1.27\end{array}$ & 0.786 & $0.0 \%$ & 2 & 1.11 & $\begin{array}{c}0.90 \text { to } \\
1.37\end{array}$ & 0.317 & $0.0 \%$ & 2 & 1.06 & $\begin{array}{c}0.86 \text { to } \\
1.30\end{array}$ & 0.606 & $0.0 \%$ \\
\hline & Mixed & 3 & 1.13 & $\begin{array}{c}0.91 \text { to } \\
1.40\end{array}$ & 0.282 & $78.8 \%$ & 1 & 1.11 & $\begin{array}{c}0.99 \text { to } \\
1.25\end{array}$ & 0.082 & NA & 2 & 0.84 & $\begin{array}{c}0.71 \text { to } \\
1.00\end{array}$ & 0.051 & $0.0 \%$ \\
\hline \multirow[t]{3}{*}{ Continent } & $\begin{array}{c}\text { North } \\
\text { America }\end{array}$ & 7 & 1.04 & $\begin{array}{c}0.94 \text { to } \\
1.15\end{array}$ & 0.486 & $53.0 \%$ & 5 & 1.08 & $\begin{array}{c}0.99 \text { to } \\
1.17\end{array}$ & 0.084 & $0.0 \%$ & 6 & 0.96 & $\begin{array}{c}0.87 \text { to } \\
1.07\end{array}$ & 0.468 & $16.7 \%$ \\
\hline & Europe & 5 & 1.24 & $\begin{array}{c}1.01 \text { to } \\
1.54\end{array}$ & 0.044 & $75.9 \%$ & 1 & 0.74 & $\begin{array}{c}0.59 \text { to } \\
0.92\end{array}$ & 0.007 & NA & 3 & 0.90 & $\begin{array}{c}0.78 \text { to } \\
1.04\end{array}$ & 0.155 & $44.3 \%$ \\
\hline & Asia & 3 & 0.99 & $\begin{array}{c}0.70 \text { to } \\
1.41\end{array}$ & 0.971 & $52.2 \%$ & 3 & 1.09 & $\begin{array}{c}0.94 \text { to } \\
1.26\end{array}$ & 0.238 & $0.0 \%$ & 2 & 1.11 & $\begin{array}{c}0.93 \text { to } \\
1.32\end{array}$ & 0.249 & $0.0 \%$ \\
\hline \multirow[t]{2}{*}{ Design type } & Prospective & 6 & 1.08 & $\begin{array}{c}0.97 \text { to } \\
1.20\end{array}$ & 0.167 & $53.4 \%$ & 3 & 0.93 & $\begin{array}{c}0.74 \text { to } \\
1.17\end{array}$ & 0.543 & $81.1 \%$ & 4 & 0.85 & $\begin{array}{c}0.77 \text { to } \\
0.95\end{array}$ & 0.003 & $0.0 . \%$ \\
\hline & Retrospective & 9 & 1.11 & $\begin{array}{c}0.94 \text { to } \\
1.32\end{array}$ & 0.213 & $71.4 \%$ & 6 & 1.10 & $\begin{array}{c}0.99 \text { to } \\
1.23\end{array}$ & 0.067 & $0.0 \%$ & 7 & 1.03 & $\begin{array}{c}0.95 \text { to } \\
1.11\end{array}$ & 0.499 & $0.0 \%$ \\
\hline \multirow[t]{2}{*}{$\begin{array}{l}\text { Control } \\
\text { source }\end{array}$} & Hospital & 6 & 0.98 & $\begin{array}{c}0.87 \text { to } \\
1.10\end{array}$ & 0.718 & $0.0 \%$ & 5 & 1.09 & $\begin{array}{c}0.97 \text { to } \\
1.23\end{array}$ & 0.129 & $0.0 \%$ & 4 & 1.09 & $\begin{array}{c}0.96 \text { to } \\
1.24\end{array}$ & 0.182 & $0.0 \%$ \\
\hline & Population & 9 & 1.15 & $\begin{array}{c}1.02 \text { to } \\
1.31\end{array}$ & 0.026 & $75.0 \%$ & 4 & 0.98 & $\begin{array}{c}0.81 \text { to } \\
1.18\end{array}$ & 0.798 & $74.3 \%$ & 7 & 0.92 & $\begin{array}{c}0.84 \text { to } \\
1.00\end{array}$ & 0.041 & $18.1 \%$ \\
\hline \multirow[t]{3}{*}{ Genotyping } & MassARRAY & 3 & 1.08 & $\begin{array}{c}1.00 \text { to } \\
1.18\end{array}$ & 0.052 & $0.0 \%$ & 1 & 0.94 & $\begin{array}{c}0.78 \text { to } \\
1.14\end{array}$ & 0.539 & NA & 3 & 0.92 & $\begin{array}{c}0.83 \text { to } \\
1.01\end{array}$ & 0.078 & $0.0 \%$ \\
\hline & PCR-related & 6 & 1.18 & $\begin{array}{c}0.89 \text { to } \\
1.58\end{array}$ & 0.254 & $74.3 \%$ & 3 & 1.09 & $\begin{array}{c}0.94 \text { to } \\
1.26\end{array}$ & 0.238 & $0.0 \%$ & 2 & 1.11 & $\begin{array}{c}0.93 \text { to } \\
1.32\end{array}$ & 0.249 & $0.0 \%$ \\
\hline & TaqMan & 6 & 1.03 & $\begin{array}{c}0.91 \text { to } \\
1.17\end{array}$ & 0.626 & $55.5 \%$ & 5 & 1.03 & $\begin{array}{c}0.87 \text { to } \\
1.22\end{array}$ & 0.738 & $66.2 \%$ & 6 & 0.96 & $\begin{array}{c}0.84 \text { to } \\
1.10\end{array}$ & 0.571 & $41.5 \%$ \\
\hline \multirow[t]{2}{*}{ Validation } & N.R. & 6 & 1.15 & $\begin{array}{c}1.04 \text { to } \\
1.27\end{array}$ & 0.004 & $12.7 \%$ & 0 & & & & & 3 & 0.91 & $\begin{array}{c}0.81 \text { to } \\
1.02\end{array}$ & 0.082 & $0.0 \%$ \\
\hline & YES & 9 & 1.07 & $\begin{array}{c}0.93 \text { to } \\
1.23\end{array}$ & 0.353 & $72.2 \%$ & 9 & 1.04 & $\begin{array}{c}0.96 \text { to } \\
1.30\end{array}$ & 0.490 & $46.8 \%$ & 8 & 1.00 & $\begin{array}{c}0.90 \text { to } \\
1.10\end{array}$ & 0.914 & $33.0 \%$ \\
\hline \multirow[t]{2}{*}{$\begin{array}{l}\text { Age- } \\
\text { matched }\end{array}$} & N.R. & 6 & 1.16 & $\begin{array}{c}0.89 \text { to } \\
1.52\end{array}$ & 0.263 & $79.0 \%$ & 3 & 1.12 & $\begin{array}{c}0.96 \text { to } \\
1.30\end{array}$ & 0.157 & $0.0 \%$ & 3 & 1.09 & $\begin{array}{c}0.94 \text { to } \\
1.27\end{array}$ & 0.243 & $0.0 \%$ \\
\hline & YES & 9 & 1.07 & $\begin{array}{c}0.99 \text { to } \\
1.17\end{array}$ & 0.106 & $46.9 \%$ & 6 & 1.01 & $\begin{array}{c}0.88 \text { to } \\
1.15\end{array}$ & 0.940 & $62.5 \%$ & 8 & 0.93 & $\begin{array}{c}0.86 \text { to } \\
1.01\end{array}$ & 0.092 & $22.5 \%$ \\
\hline \multirow[t]{2}{*}{ Sample size } & $<600$ & 8 & 1.19 & $\begin{array}{c}0.96 \text { to } \\
1.47\end{array}$ & 0.111 & $66.9 \%$ & 4 & 1.11 & $\begin{array}{c}0.97 \text { to } \\
1.28\end{array}$ & 0.135 & $0.0 \%$ & 4 & 1.06 & $\begin{array}{c}0.92 \text { to } \\
1.22\end{array}$ & 0.461 & $0.0 \%$ \\
\hline & $\geq 600$ & 7 & 1.03 & $\begin{array}{c}0.96 \text { to } \\
1.11\end{array}$ & 0.430 & $37.8 \%$ & 5 & 0.99 & $\begin{array}{c}0.86 \text { to } \\
1.15\end{array}$ & 0.902 & $65.5 \%$ & 7 & 0.94 & $\begin{array}{c}0.86 \text { to } \\
1.02\end{array}$ & 0.134 & $30.0 \%$ \\
\hline \multirow[t]{2}{*}{$\begin{array}{l}\text { Quality } \\
\text { score }\end{array}$} & $\leq 9$ & 12 & 1.14 & $\begin{array}{c}1.00 \text { to } \\
1.29\end{array}$ & 0.049 & $65.8 \%$ & 6 & 1.04 & $\begin{array}{c}0.88 \text { to } \\
1.24\end{array}$ & 0.641 & $60.3 \%$ & 9 & 0.97 & $\begin{array}{c}0.88 \text { to } \\
1.06\end{array}$ & 0.466 & $37.2 \%$ \\
\hline & $>9$ & 3 & 0.99 & $\begin{array}{c}0.92 \text { to } \\
1.07\end{array}$ & 0.758 & $0.0 \%$ & 3 & 1.06 & $\begin{array}{c}0.96 \text { to } \\
1.14\end{array}$ & 0.246 & $4.8 \%$ & 2 & 0.95 & $\begin{array}{c}0.83 \text { to } \\
1.09\end{array}$ & 0.476 & $0.0 \%$ \\
\hline $\begin{array}{l}\text { Controls, } \\
\text { age }\end{array}$ & $>50$ years & 8 & 1.15 & $\begin{array}{c}0.96 \text { to } \\
1.37\end{array}$ & 0.130 & $77.3 \%$ & 4 & 1.12 & $\begin{array}{c}1.02 \text { to } \\
1.23\end{array}$ & 0.017 & $0.0 \%$ & 5 & 0.96 & $\begin{array}{c}0.86 \text { to } \\
1.06\end{array}$ & 0.412 & $5.2 \%$ \\
\hline
\end{tabular}

Abbreviations: OR: odds ratio; 95\% CI: 95 per cent confidence interval; $I$ : inconsistency index; PCR: polymerase chain reaction; N.R.: not reported. 
mRNA expression [32], in some kind of agreement with the findings from the present meta-analysis. Moreover, a five-year follow-up study indicated that the CC genotype of $-592 \mathrm{~A}>\mathrm{C}$ polymorphism in association with higher relative mRNA expression exhibited a decreased chance of survival among PCa patients [33]. We therefore developed a working hypothesis that the $-592 \mathrm{~A}>\mathrm{C}$ polymorphism may serve as a candidate genetic marker predictive of risk for PCa by altering IL-10 expression.

Differing from previous meta-analyses, we in this meta-analysis comprehensively probed into potential origins of between-study heterogeneity by both subgrouped analyses and meta-regression analyses. Our findings suggested that ethnicity might be a potential origin of heterogeneity, in view of discrepant estimates between IL-10 genetic polymorphisms and PCa risk. It is easily understood that linkage pattern in human genomes varies during evolution in populations of different ethnic backgrounds [34], which, at least in part, can interpret the wide differences in the frequency of $\mathrm{PCa}$ across ethnicities. Currently, $\mathrm{PCa}$ is one of the most common malignancies in Western countries and an emerging malignancy in developing nations [35]. Besides the differences in styles and standards of living, studies in families have suggested that $\mathrm{PCa}$ is genetically determined [36]. The genetic basis of PCa is complex and currently not fully understood $[37,38]$. IL-10 as a potential functional candidate needs further in-vitro and in-vivo experimental investigations. On the other hand, we also found that design type and control source were the other two potential contributors interpreting between-study heterogeneity in the present meta-analysis. It is widely accepted that case-control studies are often prone to selection bias that often occurs, if the cases are not representative of all cases within the population and the controls are not representative of the population where the cases are from $[39,40]$. It is worth noting that our further sub-grouped analyses found that association of the $-592 \mathrm{~A}>\mathrm{C}$ polymorphism with $\mathrm{PCa}$ risk was strongly potentiated in both prospective and population-based studies, indicative of the robustness of our findings. Nevertheless, considering insufficient statistical power in sub-grouped analyses, we should underscore the necessity for future replication studies with a larger sample size.

Several limitations of the present meta-analysis deserved comments. Firstly, the probability of publication bias was always a concern for a meta-analysis [41], because our results were merely geared on published
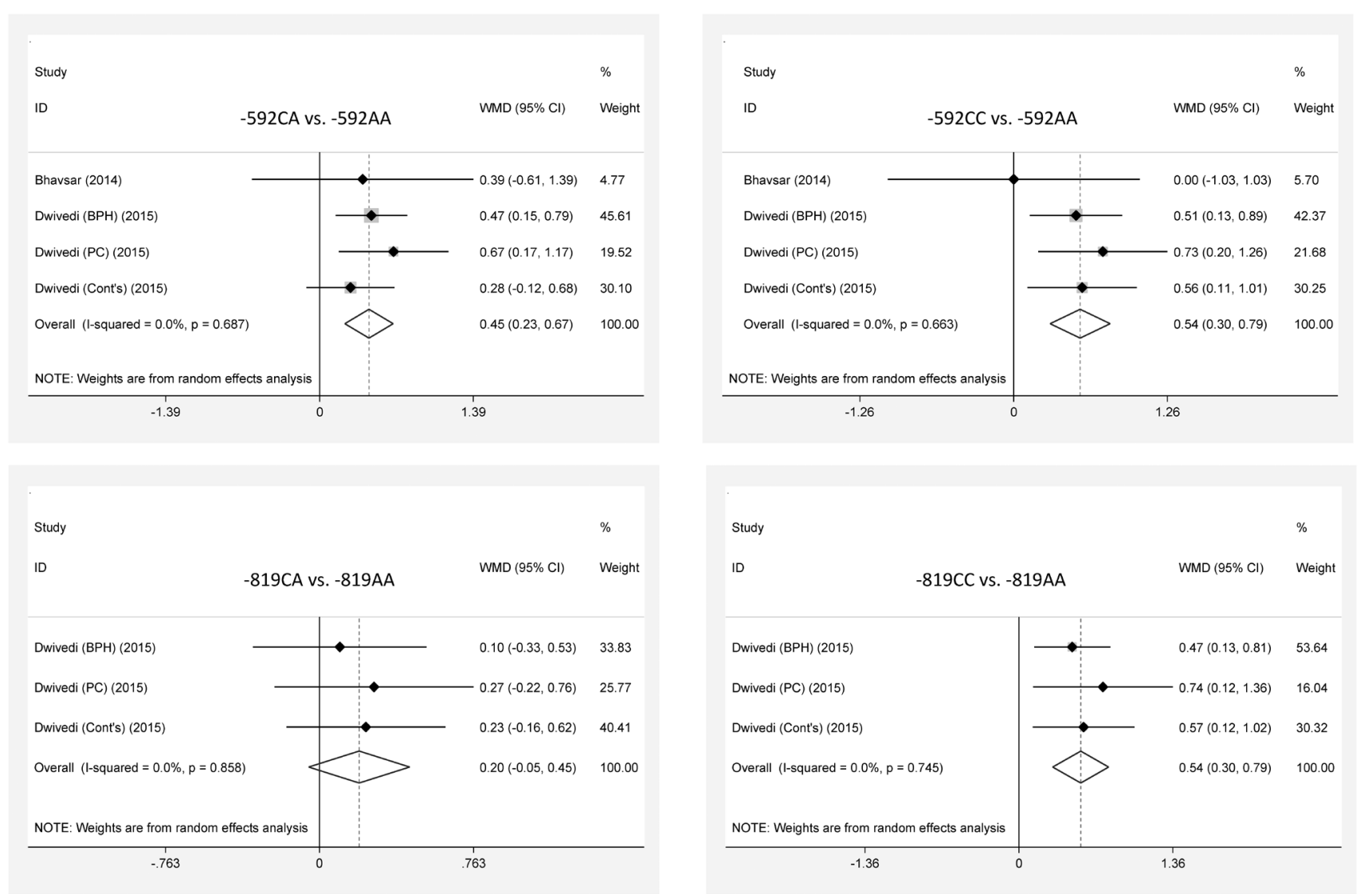

Figure 4: The forest plots for interleukin-10 gene $-819 \mathrm{~T}>\mathrm{C}$ and $-592 \mathrm{~A}>\mathrm{C}$ polymorphisms on peripheral blood interleukin-10 variation $(\mathrm{mg} / \mathrm{dL})$. 
articles from the English-language journals. In addition, our filled funnel plots suggested missing studies for $-819 \mathrm{~T}>\mathrm{C}$ and $-592 \mathrm{~A}>\mathrm{C}$ polymorphisms, while no statistical significance was detected by both Begg's and Egger's tests. Nonetheless, we were unable to exclude the possible existence of publication bias merely based on statistical tests, which can be minimized by incorporating more and more such studies. Secondly, the limited selection of IL-10 genetic polymorphisms was another concern, because only 4 polymorphisms were investigated in association with PCa risk. Thirdly, the interaction of IL10 genetic polymorphisms with environmental factors was unable to be explored, because a prospective study found that IL-10 gene promoter polymorphisms interacting with tobacco exposure may alter the susceptibility risk and severity of PCa [42]. Fourthly, other origins of betweenstudy heterogeneity remained an open question, such as diets, lifestyles, physical activity and so forth, because these data were unavailable for us. Fifthly, most studies in this meta-analysis enrolled subjects from Western countries, and it was premature to extrapolate our findings to the other races or ethnicities.

In sum, our meta-analytical findings suggested that IL-10 gene -592A $>$ C polymorphism may represent a promising candidate locus for the occurrence of $\mathrm{PCa}$, and further signified a contributing role of this polymorphism in prostate carcinogenesis. Further studies covering more genome regions on IL-10 gene and related inflammatory genes are warranted among diverse ethnic groups to gain a deeper insight into the impact of IL-10 genetic alterations on peripheral blood IL-10 variation and PCa risk, which can aid in dissecting the molecular mechanisms of PCa for further therapeutic targeting.

\section{MATERIALS AND METHODS}

\section{Study protocol}

This meta-analysis is geared on genetic observational studies. The conduct of this meta-analysis methodologically accords with the chief protocols of the Meta-analysis Of Observational Studies in Epidemiology (MOOSE) statement [43].

\section{Literature retrieval}

Retrieval of published articles was confined to electronic sources of Medline (PubMed), EMBASE (Excerpt Medica Database) and Web of Knowledge. Key subjects for retrieval consisted of ("prostate cancer" or "prostate carcinoma") in the Title and ("interleukin-10" or "interleukin 10 " or "IL-10" or "cytokine" or "inflammatory" or "inflammation") in the Title/Abstract and ("genetic" or "polymorphism" or "variant" or "mutation" or "allele" or "genotype" or "circulating" or "plasma" or "serum" or "peripheral blood") in the
Abstract. The last retrieval date was November 14, 2016. Articles written in non-English languages were ignored. Citations of retrieved articles and previous meta-analyses were also inspected. Literature retrieval was fulfilled by 2 researchers (Dan Wang and Fang Liu).

\section{Inclusive criteria}

As the purport of this meta-analysis was to investigate the impact of IL-10 gene all potential polymorphisms on peripheral blood IL-10 variation and PCa risk, articles were includable if they met the three criteria simultaneously, as follows: (i) study subjects were composed of human adults (aged 18 years old or over); (ii) at least one polymorphism in IL-10 gene was determined by standard methods, and only the polymorphism assessed by three or more independent studies was meta-analyzed; (iii) the genotypes or if unavailable the alleles of assessed polymorphism(s) were delivered between PCa patients and controls or mean peripheral blood IL-10 level along with its standard deviation were delivered across genotypes of the polymorphism under investigation in $\mathrm{PCa}$ patients or controls or both. According to the $2^{\text {nd }}$ inclusive criteria, 4 polymorphisms absorbed our attention in the present study, and they were $-1082 \mathrm{G}>\mathrm{A}(\mathrm{rs} 1800896),-819 \mathrm{~T}>\mathrm{C}$ $(\mathrm{rs} 1800871), \quad-592 \mathrm{~A}>\mathrm{C} \quad(\mathrm{rs} 1800872)$ and $210 \mathrm{~T}>\mathrm{C}$ (rs3024496).

\section{Quality appraisal}

Quality of the articles that met above-listed inclusive criteria was justified by producing a quality score based on 7 respects of a genetic association study (more details seen in Supplementary Table 1). This quality score was coined by Thakkinstian et al. in 2005 [44], and its range spanned from 0 (the worst) to 12 (the best). Quality appraisal was implemented independently by 2 researchers who were responsible for literature retrieval, and a discussion was made until every respect was entirely consistent by comparison.

\section{Information collection}

Anthropometric, clinical and genetic data were excerpted from each assessable study in this meta-analysis by 2 researchers (Dan Wang and Fang Liu), as follows: family name of the first author, publishing year, sampling region, ethnicity, design type, control source (hospitalbased and population-based), genotyping procedure, (internal - using the same genotyping method or external - using a different genotyping method in some randomlyselected samples) genotype validation, age-matched status, study sample size, mean age, per cent of current or ever smokers, family PCa history, prostate specific antigen (PSA), the genotypes of 4 above-listed polymorphisms between $\mathrm{PCa}$ patients and controls, mean (standard deviation) of peripheral blood IL-10 level in PCa patients 
or controls or both. Consistency of data excerpted by the 2 researchers was tested with any disagreement resolved through discussing.

\section{Statistical analysis}

The impact of IL-10 gene 4 polymorphisms on peripheral blood IL-10 variation and PCa risk was respectively signified with weighted mean difference (WMD) and odds ratio (OR), along with 95 per cent confidence interval (95\% CI) under either a fixed-effects model in case of non-significant heterogeneity or a random-effects model in otherwise case. Significance of between-study heterogeneity was connoted by the $I^{2}$, the acronym for inconsistency index, which characterized the per cent of variability due to heterogeneity rather than due to chance. Heterogeneity is judged significant if the $I^{2}$ overpasses 50 per cent [45]. To probe into potential origins of heterogeneity, sub-grouped analyses per ethnicity, continent, design type, control source, genotyping procedure, genotype validation, age-matched status, study sample size, quality score and controls' mean age ( $>50$ years old) were respectively applied. In addition, meta-regression analyses were applied with embracing age, per cent of smokers, family PCa history and PSA as independent variables to further interpret additional origins of between-study heterogeneity. Publication bias was graphically judged from the Begg's and filled funnel plots, along with the Begg's and Egger's regression tests. All statistical analyses were achieved by aid of the Stata software version 11.0 for the Windows 10.0.

\section{Abbreviations}

IL-10: interleukin-10; PCa: prostate cancer; PCR: polymerase chain reaction; OR: odds ratio; 95\% CI: 95 per cent confidence interval; WMD: weighted mean difference; $I^{2}$ : inconsistency index; MOOSE: Metaanalysis Of Observational Studies in Epidemiology; EMBASE: Excerpt Medica Database.

\section{Author contributions}

GT, JM, BW planned and designed the study; DW, FL contributed to literature search and data acquisition; TM, CY, JL, XQ, CY, WJ, XW, XR did the data preparation, quality control and data analysis; GT, JM, BW, TM, CY wrote and revised the manuscript. All authors approved the final version of the submitted manuscript.

\section{CONFLICTS OF INTEREST}

There are no competing interests.

\section{GRANT SUPPORT}

This work is supported by the Taishan Scholars Construction Engineering, National Natural Science Foundation of China (81400771, 31671139 and 81641074), the Shandong Excellent Young Scientist Award (ZR2016JL026), Shandong Provincial Natural Science Foundation (ZR2014HL073), Shandong Provincial Science and Technology Plan (J14LE01 and J15LK03), Yantai Science and Technology Plan (2015ZH083) and Binzhou Medical University Scientific Research Funds (BY2013KYQD17 and BY2013KYQD18).

\section{REFERENCES}

1. Perner S, Cronauer MV, Schrader AJ, Klocker H, Culig Z, Baniahmad A. Adaptive responses of androgen receptor signaling in castration-resistant prostate cancer. Oncotarget. 2015; 6:35542-35555. doi: 10.18632/oncotarget.4689.

2. Hsing AW, Tsao L, Devesa SS. International trends and patterns of prostate cancer incidence and mortality. Int J Cancer. 2000; 85:60-67.

3. Siegel RL, Miller KD, Jemal A. Cancer statistics, 2016. CA Cancer J Clin. 2016; 66:7-30.

4. Taverna G, Pedretti E, Di Caro G, Borroni EM, Marchesi F, Grizzi F. Inflammation and prostate cancer: friends or foe? Inflamm Res. 2015; 64:275-286.

5. Park SY, Na Y, Lee MH, Seo JS, Lee YH, Choi KC, Choi HK, Yoon HG. SUMOylation of TBL1 and TBLR1 promotes androgen-independent prostate cancer cell growth. Oncotarget. 2016; 7:41110-41122. doi: 10.18632/ oncotarget.9002.

6. Lin HC, Lin JY. Immune cell-conditioned media suppress prostate cancer PC-3 cell growth correlating with decreased proinflammatory/anti-inflammatory cytokine ratios in the media using 5 selected crude polysaccharides. Integr Cancer Ther. 2016; 15:NP13-NP25.

7. Mocellin S, Marincola FM, Young HA. Interleukin-10 and the immune response against cancer: a counterpoint. J Leukoc Biol. 2005; 78:1043-1051.

8. Srivastava M, Ranjan A, Choudhary JK, Tripathi MK, Verma S, Dixit VK, Nath G, Jain AK. Role of proinflammatory cytokines (interferon gamma) and anti-inflammatory cytokine (interleukin-10) gene polymorphisms in chronic hepatitis B infection: an Indian scenario. J Interferon Cytokine Res. 2014; 34:547-551.

9. Dean M, Lou H. Genetics and genomics of prostate cancer. Asian J Androl. 2013; 15:309-313.

10. Eeles RA, Kote-Jarai Z, Giles GG, Olama AA, Guy M, Jugurnauth SK, Mulholland S, Leongamornlert DA, Edwards SM, Morrison J, Field HI, Southey MC, Severi G, 
et al. Multiple newly identified loci associated with prostate cancer susceptibility. Nat Genet. 2008; 40:316-321.

11. Pakkanen S, Kujala PM, Ha N, Matikainen MP, Schleutker J, Tammela TL. Clinical and histopathological characteristics of familial prostate cancer in Finland. BJU Int. 2012; 109:557-563.

12. Anderson DE, Badzioch MD. Familial effects of prostate and other cancers on lifetime breast cancer risk. Breast Cancer Res Treat. 1993; 28:107-113.

13. Horvat V, Mandic S, Marczi S, Mrcela M, Galic J. Association of IL-1beta and IL-10 polymorphisms with prostate cancer risk and grade of disease in Eastern Croatian population. Coll Antropol. 2015; 39:393-400.

14. VanCleave TT, Moore JH, Benford ML, Brock GN, Kalbfleisch T, Baumgartner RN, Lillard JW Jr, Kittles RA, Kidd LC. Interaction among variant vascular endothelial growth factor (VEGF) and its receptor in relation to prostate cancer risk. Prostate. 2010; 70:341-352.

15. Zabaleta J, Lin HY, Sierra RA, Hall MC, Clark PE, Sartor $\mathrm{OA}, \mathrm{Hu} \mathrm{JJ}$, Ochoa AC. Interactions of cytokine gene polymorphisms in prostate cancer risk. Carcinogenesis. 2008; 29:573-578.

16. Michaud DS, Daugherty SE, Berndt SI, Platz EA, Yeager M, Crawford ED, Hsing A, Huang WY, Hayes RB. Genetic polymorphisms of interleukin-1B (IL-1B), IL-6, IL-8, and IL-10 and risk of prostate cancer. Cancer Res. 2006; 66:4525-4530.

17. Xu J, Lowey J, Wiklund F, Sun J, Lindmark F, Hsu FC, Dimitrov L, Chang B, Turner AR, Liu W, Adami HO, Suh E, Moore JH, et al. The interaction of four genes in the inflammation pathway significantly predicts prostate cancer risk. Cancer Epidemiol Biomarkers Prev. 2005; 14:2563-2568.

18. Zou YF, Wang F, Feng XL, Tian YH, Tao JH, Pan FM, Huang F. Lack of association of IL-10 gene polymorphisms with prostate cancer: evidence from 11,581 subjects. Eur J Cancer. 2011; 47:1072-1079.

19. Shao N, Xu B, Mi YY, Hua LX. IL-10 polymorphisms and prostate cancer risk: a meta-analysis. Prostate Cancer Prostatic Dis. 2011; 14:129-135.

20. Winchester DA, Till C, Goodman PJ, Tangen CM, Santella RM, Johnson-Pais TL, Leach RJ, Xu J, Zheng SL, Thompson IM, Lucia MS, Lippmann SM, Parnes HL, et al. Variation in genes involved in the immune response and prostate cancer risk in the placebo arm of the Prostate Cancer Prevention Trial. Prostate. 2015; 75:1403-1418.

21. Dwivedi S, Goel A, Khattri S, Mandhani A, Sharma P, Misra S, Pant KK. Genetic variability at promoters of IL-18 (pro-) and IL-10 (anti-) inflammatory gene affects susceptibility and their circulating serum levels: an explorative study of prostate cancer patients in North Indian populations. Cytokine. 2015; 74:117-122.
22. Bhavsar NA, Bream JH, Meeker AK, Drake CG, Peskoe SB, Dabitao D, De Marzo AM, Isaacs WB, Platz EA. A peripheral circulating TH1 cytokine profile is inversely associated with prostate cancer risk in CLUE II. Cancer Epidemiol Biomarkers Prev. 2014; 23:2561-2567.

23. Ianni M, Porcellini E, Carbone I, Potenzoni M, Pieri AM, Pastizzaro CD, Benecchi L, Licastro F. Genetic factors regulating inflammation and DNA methylation associated with prostate cancer. Prostate Cancer Prostatic Dis. 2013; 16:56-61.

24. Dluzniewski PJ, Wang MH, Zheng SL, De Marzo AM, Drake CG, Fedor HL, Partin AW, Han M, Fallin MD, Xu J, Isaacs WB, Platz EA. Variation in IL10 and other genes involved in the immune response and in oxidation and prostate cancer recurrence. Cancer Epidemiol Biomarkers Prev. 2012; 21:1774-1782.

25. Liu J, Song B, Bai X, Liu W, Li Z, Wang J, Zheng Y, Wang Z. Association of genetic polymorphisms in the interleukin-10 promoter with risk of prostate cancer in Chinese. BMC Cancer. 2010; 10:456.

26. Wang MH, Helzlsouer KJ, Smith MW, Hoffman-Bolton JA, Clipp SL, Grinberg V, De Marzo AM, Isaacs WB, Drake CG, Shugart YY, Platz EA. Association of IL10 and other immune response- and obesity-related genes with prostate cancer in CLUE II. Prostate. 2009; 69:874-885.

27. Kesarwani P, Ahirwar DK, Mandhani A, Singh AN, Dalela D, Srivastava AN, Mittal RD. IL-10 -1082 G>A: a risk for prostate cancer but may be protective against progression of prostate cancer in North Indian cohort. World J Urol. 2009; 27:389-396.

28. Omrani MD, Bazargani S, Bageri M. Interlukin-10, Interferon- $\gamma$ and tumor necrosis factor- $\alpha$ genes variation in prostate cancer and benign prostatic hyperplasia. Curr Urol. 2008; 2:175-180.

29. Faupel-Badger JM, Kidd LC, Albanes D, Virtamo J, Woodson K, Tangrea JA. Association of IL-10 polymorphisms with prostate cancer risk and grade of disease. Cancer Causes Control. 2008; 19:119-124.

30. Eder T, Mayer R, Langsenlehner U, Renner W, Krippl P, Wascher TC, Pummer K, Kapp KS. Interleukin-10 [ATA] promoter haplotype and prostate cancer risk: a populationbased study. Eur J Cancer. 2007; 43:472-475.

31. McCarron SL, Edwards S, Evans PR, Gibbs R, Dearnaley DP, Dowe A, Southgate C, Easton DF, Eeles RA, Howell WM. Influence of cytokine gene polymorphisms on the development of prostate cancer. Cancer Res. 2002; 62:3369-3372.

32. Claudino M, Trombone AP, Cardoso CR, Ferreira SB Jr, Martins W Jr, Assis GF, Santos CF, Trevilatto PC, Campanelli AP, Silva JS, Garlet GP. The broad effects of the functional IL-10 promoter-592 polymorphism: modulation of IL-10, TIMP-3, and OPG expression and their association 
with periodontal disease outcome. J Leukoc Biol. 2008; 84:1565-1573.

33. Dwivedi S, Goel A, Mandhani A, Khattri S, Sharma P, Misra S, Pant KK. Functional genetic variability at promoters of pro-(IL-18) and anti-(IL-10) inflammatory affects their mRNA expression and survival in prostate carcinoma patients: five year follow-up study. Prostate. 2015; 75:1737-1746.

34. Patin E, Barreiro LB, Sabeti PC, Austerlitz F, Luca F, Sajantila A, Behar DM, Semino O, Sakuntabhai A, Guiso N, Gicquel B, McElreavey K, Harding RM, et al. Deciphering the ancient and complex evolutionary history of human arylamine N-acetyltransferase genes. Am J Hum Genet. 2006; 78:423-436.

35. Haas GP, Delongchamps N, Brawley OW, Wang CY, de la Roza G. The worldwide epidemiology of prostate cancer: perspectives from autopsy studies. Can J Urol. 2008; 15:3866-3871.

36. Gansmo LB, Vatten L, Romundstad P, Hveem K, Ryan BM, Harris CC, Knappskog S, Lonning PE. Associations between the MDM2 promoter P1 polymorphism del1518 (rs3730485) and incidence of cancer of the breast, lung, colon and prostate. Oncotarget. 2016; 7:28637-28646. doi: 10.18632/oncotarget.8705.

37. Stone L. Genetics: known prostate cancer risk loci-guilty by association? Nat Rev Urol. 2015; 12:416.

38. Hutchinson L. Genetics: predictor for prostate cancer. Nat Rev Clin Oncol. 2011; 8:193.

39. Walsh MC, Trentham-Dietz A, Gangnon RE, Nieto FJ, Newcomb PA, Palta M. Selection bias in population-based cancer case-control studies due to incomplete sampling frame coverage. Cancer Epidemiol Biomarkers Prev. 2012; 21:881-886.

40. Morabia A. Case-control studies in clinical research: mechanism and prevention of selection bias. Prev Med. 1997; 26:674-677.

41. Sedgwick P. What is publication bias in a meta-analysis? BMJ. 2015; 351:h4419.

42. Dwivedi S, Singh S, Goel A, Khattri S, Mandhani A, Sharma P, Misra S, Pant KK. Pro-(IL-18) and anti(IL-10) inflammatory promoter genetic variants (intrinsic factors) with tobacco exposure (extrinsic factors) may influence susceptibility and severity of prostate carcinoma: a prospective study. Asian Pac J Cancer Prev. 2015; 16:3173-3181.

43. Stroup DF, Berlin JA, Morton SC, Olkin I, Williamson GD, Rennie D, Moher D, Becker BJ, Sipe TA, Thacker SB. Meta-analysis of observational studies in epidemiology: a proposal for reporting. Meta-analysis Of Observational Studies in Epidemiology (MOOSE) group. JAMA. 2000; 283:2008-2012.

44. Thakkinstian A, McEvoy M, Minelli C, Gibson P, Hancox B, Duffy D, Thompson J, Hall I, Kaufman J, Leung TF, Helms PJ, Hakonarson H, Halpi E, et al. Systematic review and meta-analysis of the association between beta2adrenoceptor polymorphisms and asthma: a HuGE review. Am J Epidemiol. 2005; 162:201-211.

45. Bowden J, Tierney JF, Copas AJ, Burdett S. Quantifying, displaying and accounting for heterogeneity in the metaanalysis of RCTs using standard and generalised Q statistics. BMC Med Res Methodol. 2011; 11:41. 